\title{
The Cotton Fabric Coloring with Leucaena leucocephala Peel at Room Temperature
}

\author{
Priyanti $^{1}$, Roscha Amellia ${ }^{1}$, Ardian Khairiah ${ }^{1}$, Muhamad Hilal ${ }^{1}$, Ade \\ Maulana Putra ${ }^{1}$, Nur Arifin Andryansyah ${ }^{1}$, Ameylinda Dwi Fransiska ${ }^{1}$, \\ Maulana Malik Assyaidin¹, Zikri Chairullisan ${ }^{1}$, Rachma Fauziah $^{2}$ \\ ${ }^{1}$ State Islamic University of Syarif Hidayatullah Jakarta, Indonesia \\ ${ }^{2}$ Pusat Penelitian dan Pengembangan Kementrian Agama, Jakarta, Indonesia
}

priyantiduinjkt.ac.id

\begin{abstract}
This study aimed to utilize water stew rind of Leucaena leucocephala peel as the natural coloring for cotton fabric at room temperature to reduce heat energy but produce optimum worshippers. The natural coloring processed with mordant lime (CaCO3), alum $\mathrm{Al} 2(\mathrm{SO} 4) 3$, and ferro sulfate (FeSO4). The research found out that $L$. leucocephala peel can be used for the cotton fabric natural coloring with light brown to brown. A color produced depends on the type used in dyeing. A method of staining proved to be good because the results obtained the color field and permanent. When compared with tree mordants, color absorption with lime was better. The darker color for the same treatment could be seen. The analysis results of ironing dry generally ranged between good to excellent (scale 4-5). The benefit of $L$. leucocephala peel can be used as a natural coloring and defended its color by mordant addition.
\end{abstract}

\section{Introduction}

The textile, food, cosmetics, and medicine industries generally use dyes (Chhipa et al., 2017). These dyes are made of synthetic or natural ingredients. Artificial dyes for textile products, food, cosmetics, and medicines are more striking than natural dyes (Samanta \& Agrawal, 2009). However, synthetic dyes that are discharged into drains that run into rivers can make the waters colored and smell bad which can cause the death of photosynthetic organisms in the water ecosystem (Chhipa et al., 2017). Humans who consume the water and organisms in the waters contaminated with synthetic dyes for a long time are more prone to cancer (Samanta \& Agrawal, 2009), therefore information on natural dyes innovation is in high demand.

Fruit peels are mainly used as natural dyes for textiles, such as those from mangosteen peel (Kwartiningsih et al., 2009; Manurung, 2012) and dragon fruit peel (Evaardina et al., 2016). 
Meanwhile, information on Leucaena leucocephala as natural dye is still unavailable. This plant is mainly used as shading tree on the road side and tea or coffee plantations, as well as grown in the areas of waste (ISSG, 2008). Leucaena leucocephala is tolerant to cold temperature and dry soil at the seedling stage (Iqbar et al., 2017). The population of L. leucocephala is abundant with many fruits.

In this research, we utilized the ripe and brown fruit peels of $L$. leucocephala as a natural dye on cotton fabric. According to Kamel et al. (2009) and Chhipa et al. (2017), the dye can be obtained by adding chalk, alum $\left(\mathrm{Al}_{2} \mathrm{SO}_{4}\right)$, and ferrous sulphate $\left(\mathrm{FeSO}_{4}\right)$ as mordant. This study aimed to obtain natural coloring extracts with the addition of mordant which is safe for the environment.

\section{Materials and Methods}

\subsection{Leucaena leucocephala Fruit Collection}

Leucaena leucocephala was obtained from green open land in Kota Tangerang and Kota Tangerang Selatan (Figure 1a). The categorize of old fruit is dark chocolate which collected from 30 plant individuals with a height of $10 \mathrm{~m}$. The fruits were skinned off from the seeds and dried in the sun (Figure 1b).
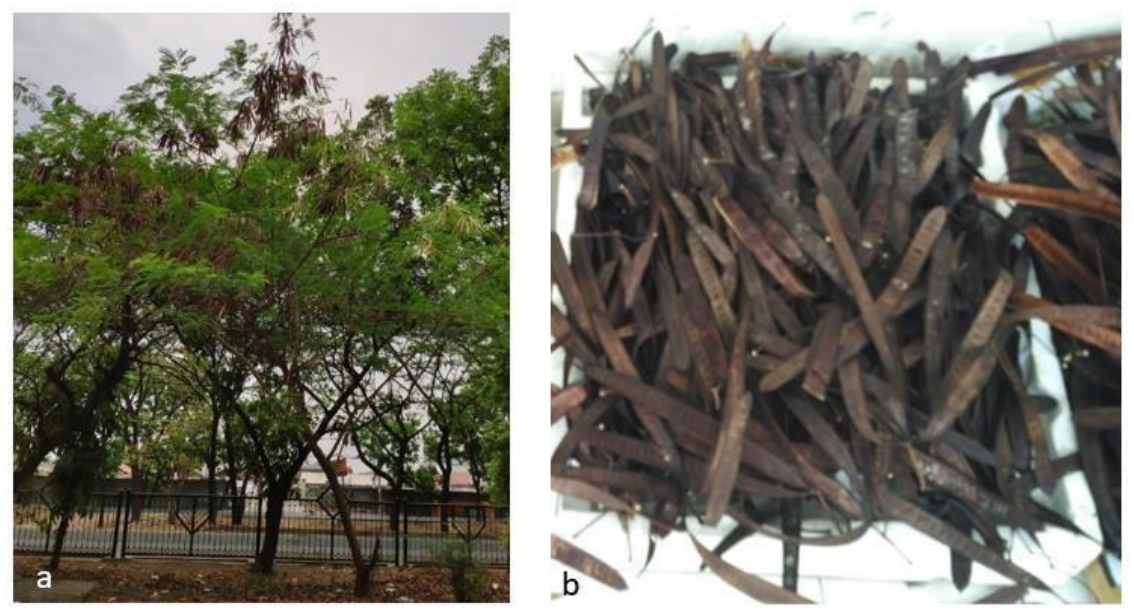

Figure 1: Leucaena leucochepala, a. Plant, b. Dried Peels

\subsection{Extraction of natural dyes}

The dried L. leucocephala peels were cut in $1 \times 1 \mathrm{~cm}$. The slices were boiled until $100{ }^{\circ} \mathrm{C}$ for 2 hours and stirred occasionally. The cooking water was then allowed to stand for 12 hours.

\subsection{Pre-Treatment of the Cotton Fabric}

Pre-treatment of the cotton fabric referred to Rini et al. (2011). The white cotton fabric $1 \times 1 \mathrm{~m}$ washed with detergent and rinsed thoroughly. A pre-mordant solution was made with $70 \mathrm{~g}$ Alum composition and $50 \mathrm{~g}$ Soda ash dissolved in $10 \mathrm{~L}$ water and boiled at $100{ }^{\circ} \mathrm{C}$ for 60 minutes. The cotton fabric has been washed and then put into a pre-mordant solution until submerged and allowed to stand for 12 hours. After that, they were washed thoroughly and then dried at room temperature. 


\subsection{Fabric Coloring}

The pre-treated cotton fabric has been soaked in the $50 \mathrm{~g}$ Turkish Red Oil (TRO) solution dissolved in the water $10 \mathrm{~L}$ for 12 hours and then dried at room temperature. The cotton fabric dipped slowly until evenly distributed in a tube containing a solution of natural dyes at $50 \mathrm{C}$ then removed and dried at room temperature. This stage is carried out continuously as much as 30 times.

\subsection{Mordanting Methods}

The dyed fabrics soaked for 12 hours into varied mordant solution tanks. Each tank consisted of $0.5 \%$ and $0.6 \%$ mordant Alum $\left(\mathrm{Al}_{2} \mathrm{SO}_{4}\right)$, Chalk $\left(\mathrm{CaCO}_{3}\right)$, and Ferrous Sulphate $\left(\mathrm{FeSO}_{4}\right)($ Table 1). After the soaking process, the fabrics dried at room temperature.

\begin{tabular}{lcc}
\hline \multicolumn{1}{c}{ Mordant } & \multicolumn{2}{c}{ Concentrasion (\%) } \\
\hline Alum $\left(\mathrm{Al}_{2} \mathrm{SO}_{4}\right)$ & 0.5 & 0.6 \\
Chalk $(\mathrm{CaCO})$ & 0.5 & 0.6 \\
$\begin{array}{l}\text { Ferrous Sulphate } \\
\text { (FeSO4) }\end{array}$ & 0.5 & 0.6 \\
\hline
\end{tabular}

Table 1: Variations in Mordant Concentration

\subsection{Color Resistance Test for Domestic and Commercial Washes}

The color resistance test consisted of discoloration, staining, dry rubbing, and wet rubbing. The changes and stains of color were descriptive by 4 people then compared to the grayscale and staining scale standards (SNI ISO 105-A02-2010 and SNI ISO 105-A03-2010). A test fabric measuring $40 \times 100$ $\mathrm{mm}$ is attached to cotton fabric and wool of the same size. The cotton and wool fabric were then sewn on one of the short sides so that the surface of the cotton and wool upholstery faces the surface of the test fabric. A total of $0.4 \%$ of ECE solution, the test fabric, and 10 steel marbles filled in the same test tube $(150 \mathrm{~mL}$ capacity). A closed tube put into the machine and turn on it in 45 minutes. the fabric rinsed two times into the water grade $3(100 \mathrm{~mL})$. put out the test fabric from a tube and then dried at room temperature. Finally, the score compared to the greyscale and staining scale.

\subsection{Dry and Wet Rub Test}

The fastness test for rubbing was carried out in 4 hours at temperature $20 \pm 2{ }^{\circ} \mathrm{C}$ with relative humidity at $65 \pm 2 \%$. The placing fabric test and polishing cloth separately solid or perforated. The 50 $\mathrm{m} 2$ scrubbing cloth has been starched, bleached, and placed in sandpaper paper at the bottom of the test paper. This could reduce the shift when was rubbing with a crock meter tested.

\subsection{Data Analysis}

The results of the fastness test for washing and rubbing are done descriptively by referring to SNI ISO 105-A02-2010 and SNI ISO 105-A03-2010 


\section{Result and Discussion}

\subsection{Result}

The peels of L. leucocephala can dye a white fabric from light brown to brown. Color locking with all concentrations of Ferrum Sulphate (FeSO4) expressed more intense colors than Chalk and Alum mordants (Table 2).

\begin{tabular}{|c|c|c|c|}
\hline No. & Mordant & Concentration (\%) & Color Result \\
\hline 1 & Control & 0 & \\
\hline 2 & Alum (Al2SO4) & 0.5 & \\
\hline 3 & Chalk (CaCO3) & 0.5 & \\
\hline 4 & Ferrum Sulphate (FeSO4) & 0.5 & \\
\hline 5 & Alum (Al2SO4) & 0.6 & \\
\hline 6 & Chalk (CaCO3) & 0.6 & \\
\hline 7 & Ferrum Sulphate (FeSO4) & 0.6 & \\
\hline
\end{tabular}

Table 2: Color Expression after Mordant Processing

Based on the grayscale and staining scale, the general color resistance test categorized poor (1-2) for both control and others. In contrast, Chalk 0.6\% has a value of 2-3 (Table 3). 
The Cotton Fabric Coloring with Leucaena leucocephala Peel at Room Temperature Priyanti et al.

\begin{tabular}{|c|c|c|c|c|c|c|}
\hline No & Mordant & $\begin{array}{c}\text { Concentration } \\
(\%)\end{array}$ & $\begin{array}{c}\text { Color } \\
\text { Change }\end{array}$ & $\begin{array}{c}\text { Color } \\
\text { Blemishes }\end{array}$ & $\begin{array}{c}\text { Dry } \\
\text { Staining }\end{array}$ & $\begin{array}{c}\text { Wet } \\
\text { Staining }\end{array}$ \\
\hline 1 & Control & 0 & 1 & $4-5$ & $4-5$ & $3-4$ \\
\hline 2 & Alum $\left(\mathrm{Al}_{2} \mathrm{SO}_{4}\right)$ & 0.5 & 2 & $4-5$ & 4 & 3 \\
\hline 3 & Lime $\left(\mathrm{CaCO}_{3}\right)$ & 0.5 & $1-2$ & $4-5$ & 4 & 3 \\
\hline 4 & $\begin{array}{l}\text { Tunjung } \\
\left(\mathrm{FeSO}_{4}\right)\end{array}$ & 0.5 & $1-2$ & $4-5$ & 4 & 3 \\
\hline 5 & Alum $\left(\mathrm{Al}_{2} \mathrm{SO}_{4}\right)$ & 0.6 & $1-2$ & $4-5$ & $4-5$ & 3 \\
\hline 6 & Lime $\left(\mathrm{CaCO}_{3}\right)$ & 0.6 & $2-3$ & $4-5$ & 4 & 3 \\
\hline 7 & $\begin{array}{l}\text { Tunjung } \\
\left(\mathrm{FeSO}_{4}\right)\end{array}$ & 0.6 & $1-2$ & $4-5$ & 4 & 3 \\
\hline
\end{tabular}

Table 3: Test value of greyscale and staining scale of varies mordants

The test the change of the best color indicated by chalk $\left(\mathrm{CaCo}_{3}\right) 0.6 \%$ compared with other experiments. With a value of 4 or 5 testings shown in color blemishes on all experiments. The same value indicated on the control of the provision of mordant alum $0.6 \%$ for dry staining while general wet staining has sufficient (3).

\subsection{Discussion}

The boiling L. leucocephala peel at $100{ }^{\circ} \mathrm{C}$ was able to produce an extract of the natural color which converts a cotton fabric white becomes colored light brown to brown (Table 1). A piece of cotton fabric has the hydroxyl (Pujilestari, 2014) that has a strength to increase the relative humidity (RH) $95 \%$ to absorb water as much as $27 \%$ from its weight (Subagiyo, 2008). The results of the study are also supporting the previous research by Konar (2011) who obtained an extract of a natural dye from Babool (Babla) and Artocarpus heterophylla bark that had been boiled with the same temperature for 120 minutes and was kept all night.

Other previous experiments were also conditioned at room temperature when dyeing and drying but the color produced was less dark (Gülümser, 2016; Moses \& Venkataraman, 2016; Daberao et al., 2016). It was because the fibers of the cotton fabric were not stretched at room temperature, so the color would be lighter than its maximum expression (Elnagar et al. 2014). The fabric is locked paler with a mordant Alum $\left(\mathrm{Al}_{2} \mathrm{SO}_{4}\right)$ than a mordant Chalk $\left(\mathrm{CaCO}_{3}\right)$ and Ferrum Sulphate $\left(\mathrm{FeSO}_{4}\right)$ which is in accordance with the results of the study by Rosyida \& Achiadi (2014), Pujilestari et al. (2016), and Chhipa et al. (2017). A mordant Ferrum Sulphate $\left(\mathrm{FeSO}_{4}\right)$ expressed darker color because the ions $\mathrm{Fe}^{2+}$ from Ferrum Sulphate was clutched with the molecules in the fiber and the dyestuff established a large and strong bond (Pujilestari et al. 2016).

The cotton fabric colored with extract of $L$. leucocephala showed the best grades (2-3) on changes in colors after soaked in a mordant Alum $\left(\mathrm{Al}_{2} \mathrm{SO}_{4}\right)$ with a concentration of $0.6 \%$. This study used a lower concentration of mordant Alum $\left(\mathrm{Al}_{2} \mathrm{SO}_{4}\right)$ solution than the cotton fabric with Acacia sp. bark extract which is by the mordant Alum $\left(\mathrm{Al}_{2} \mathrm{SO}_{4}\right) 5 \%$ (Hidayah, 2016). The lower concentration of mordant using in this research could become a reference to subsequent research so that a source of chemical materials which was discarded out in the water is safe for the life of the organism in it.

\section{Conclusion}

The extract L. leucocephala peel can be used as a natural dye on fabric. The low mordant concentration used $(0.5$ and $0.6 \%)$ is still able to lock colors on the cotton fabric and so eco-friendly. The experiment with natural dyes extracted from L. leucocephala peel still needs more condensed 
The Cotton Fabric Coloring with Leucaena leucocephala Peel at Room Temperature Priyanti et al.

coloring results and treatment at a higher temperature.

\section{Acknowledgment}

Research is funded by the BOPTN DIPA of State Islamic University Syarif Hidayatullah Jakarta in 2018.

\section{References}

Chhipa MK, Srivastav S, and Mehta N. (2017). Study of Dyeing of Cotton Fabric using Peanut Pod Natural Dyes using $\mathrm{Al}_{2} \mathrm{SO}_{4}, \mathrm{CuSO}_{4}$, and $\mathrm{FeSO}_{4}$ Mordanting Agent. International Journal of Environmental \& Agriculture Research (IJOEAR). 3(2): 36-44.

Daberao AM, Kolte PP, and Turukname RN. (2016). Cotton Dyeing with Natural Dye. International Journal of Research and Scientific Innovation (IJRSI). 3(3): 157-161.

Elnagar K, Elmaaty TA, and Raout S. (2014). Dyeing of Polyester and Polyamide Synthetic Fabrics with Natural Dyes using Ecofriendly Technique. Journal of Textile. 1: 1-8.

Evaardina, Yulianti I, and Masturi. (2016). Ekstraksi Kulit Buah Naga (Dragon Fruit) sebagai Zat Pewarna Alami pada Kain Batik. In Bahasa. Prosiding Pertemuan Ilmiah XXX HFI Jateng \& DIY. 158160.

Gülümser T. (2016). Comparison between Naturally Colored Cotton Fabric and White Cotton Fabric in Manner of Process in the Dyehouse. Tekstil ve Konfeksiyon, 26(3), 287-294.

Hidayah A. (2016). Perbandingan Uji Ketahanan Gosok Zat Warna Alam Kulit Akasia Gunung Merapi (Acacia decurrens) dengan Akasia Gunung Merbabu (Acacia mangium) pada Kain Batik Primisima. Skripsi. In Bahasa. Universitas Negeri Yogya. Yogyakarta.

Iqbar, Riana S, and Masykur. (2017). Inventarisasi Spesies Tanaman Potensial Invasive di Kawasan Perumahan PT. Arun NGL, Lhokseumawe, Aceh. In Bahasa. BioLeuser. 1(1): 20-30.

Invasive Species Specialist Group (ISSG). (2008). Global Invasive Species Database. Retrieved from: http://www.issg.org. accessed on August 30, 2019.

Kwartiningsih E, Prastika KA, and Lellis TD. (2009). Ekstraksi dan Uji Stabilitas Antosianin dari Kulit Buah Naga Super Merah (Hylocereus costaricensis). In Bahasa. Prosiding Seminar Nasional. Yogyakarta.

Manurung M. (2012). Aplikasi Kulit Buah Manggis (Garcinia mangostana) sebagai Pewarna Alami pada Kain Katun secara Pre-mordanting. In Bahasa. Journal of Chemistry. 6(2): 183-190.

Moses J and Venkataraman. (2016). Study of The Chemical Treatment on Cotton Fabrics to Increase the UV Protection and Anti-odor Retention Properties. Tekstil ve Konfeksiyon. 26(4): 400- 406.

Pujilestari T. (2014). Pengaruh Ekstraksi Zat Warna Alam dan Fiksasi terhadap Ketahanan Luntur Warna pada Kain Katun. In Bahasa. Dinamika Kerajinan dan Batik. 3(1): 31-32.

Rini S, Sugiarti, and Riswati MK. (2011). Pesona Warna Alami Indonesia. In Bahasa. Jakarta: KEHATI.

Rosyida A and Achiadi Z. (2014). Pemanfaatan Daun Jati Muda untuk Pewarnaan Kain Kapas pada Suhu Kamar. In Bahasa. Arena Tekstil. 29(2): 115-121.

Samanta AK and Agrawal P. (2009). Application of Natural Dyes on Textiles. Indian Journal of Fiber \& Textile Research. 34: 384-389.

Subagiyo PY. (2008). Tekstil Tradisional: Pengenalan Bahan dan Teknik. Artikel. In Bahasa. Studio Primatoria. Bekasi. 